\title{
Tampa Bay Sporting Goods Inc. Case
}

Michael J. Krause (E-mail: krausemj@mail.lemoyne.edu), Le Moyne College

\begin{abstract}
Providing accounting services is a business. Since business functions in a world of competition and opportunities, accountants must be willing to compete and to seize opportunities. Wrapped around a traditional core of year-end accrual accounting issues and procedures, Tampa Bay Sporting Goods Inc. case makes students experience accounting as a people business. Accounting firm partners compete for clients. Staff accountants compete to get noticed by partners. When a retail business booms so rapidly that it outgrows current accounting services, an opportunity exists for an aggressive accounting firm to prove the value that it can provide to its clients. Accounting firms must foster professional relationships both at the management and staff levels of a client's business in order to deliver successfully its services. And as the firm prospers so does the individual professional who facilitated the accomplishment. As a result of this dynamic, tasks such as preparing adjusting entries and relevant financial statements take on a new importance and urgency.
\end{abstract}

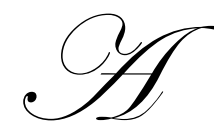

sonal assets.

the end of the year 2001, Tampa Bay Sporting Goods Inc. completed its second year of business. Prior to the year 2000, the business functioned as a partnership primarily owned by David and Erin Olson. Upon advice of legal counsel, the married couple formed a corporation to protect their per-

The Tampa Bay area has recently experienced significant population growth. A new 65,000-seat football stadium has been constructed in response to a larger fan base. And major league baseball was introduced during both the spring training and regular seasons. Due to these three factors, the interest in and the demand for sporting goods has steadily increased in the metropolitan area. Unfortunately, greater economic activity placed a strain upon available professional services like accounting and auditing. The Olson's employ a bookkeeper, James Espina, who has worked at the store since its days as a partnership entity. James, like the rest of the staff, struggles to cope with transaction volume and complexity. As the entity needed to secure more types of financing, preparation of professionally sound general purpose financial statements became a necessity to keep creditors currently informed, and to help Mr. and Mrs. Olson formulate future strategic plans. To expedite the development of such crucial information, the Olson's hired Murray and Spiwak, CPA's, to monitor the bookkeeper. In addition, the CPA's were retained to compile, review or audit, the annual financial report, depending upon creditors' demands.

Murray and Spiwak assigned a senior staff accountant, Greg Chesley, to investigate how Tampa Bay Sporting Goods Inc. implements the accounting cycle. Don Murray, the partner-in-charge of the engagement, gave Chesley the additional task of training James Espina. According to Murray's instructions, Espina's training should focus on developing a working relationship with Chesley. That relationship in turn would establish standard practices that should facilitate annual financial statement preparation. Murray's ultimate goal was to minimize the CPA firm's bookkeeping tasks so as to free-up time to bill for management consulting and tax planning services. In Murray's judgment, Tampa Bay Sporting Goods would develop into a significant client.

Only a couple of months ago, Greg Chesley relocated to the Tampa Bay area from Upstate New York. Chesley was very excited about landing a job with a dynamic local CPA firm. However, he was greatly disappointed by Florida pay levels. Rather than letting low compensation rates deter him, Chesley set out to prove to the firm's partners that he was a valuable asset to the firm and should be rewarded accordingly.

Readers with comments or questions are encouraged to contact the author via email. 
In early December 2001, Chesley arranged an initial meeting with James Espina to inspect the facilities and to examine the general ledger as posted through November 30, 2001. The meeting ended after Chesley transcribed an unadjusted trial balance at 11/30/01. Then during the middle of January 2002, Chesley used that November trial balance as a model format for the unadjusted trial balance at 12/31/01 that he organized using Microsoft's Excel (see Appendix 1). After Chesley completed the unadjusted trial balance at 12/31/01, he used it to prepare financial statements. To avoid confusion with the final version of Tampa Bay Sporting Goods' annual report, Chesley marked the statements "preliminary calculations" (see Appendix 2). Chesley took this unusual step as a way to document the value that his professional interventions would add to Tampa Bay Sporting Goods' financial statements ' final version.

Don Murray deliberately gives senior staff accountants only general instructions and goals in dealing with clients. He does so for two reasons. First, Murray manages his time very carefully so as to maximize hours that he can legitimately bill customers at his premium rate. Second, he constantly observes a staff member's initiative with a view towards granting further responsibilities and resulting promotions. Therefore, Chesley took upon himself the task of establishing a program that would: (1) document the bookkeeping and accounting practices of Tampa Bay Sporting Goods; and (2) would also assist in the preparation of standard review and recording procedures necessary to expedite financial statement preparation. Chesley wrote the program during the middle of December 2001. (See Appendix 3.)

During the course of implementing his program, Greg Chesley made many observations and followed up with specific actions. When Chesley analyzed the bank reconciliation, he found that a deposit in transit went unrecorded in the December 2001 cash receipts journal. This deposit represented the store's cash sales for the last two days of December. The amount was $\$ 9,006$. Tampa Bay Sporting Goods Inc. uses a periodic inventory system to account for merchandise. On January 1, 2002, Chesley and Espina counted the merchandise while the store was closed. The cost associated with the counted units amounted to $\$ 302,046$. The next day Espina alone identified unused office supplies with a balance of $\$ 1,878$.

Shortly after the merchandise inventory count, Chesley sent Espina a memo that explained Murray and Spiwak's standard advice to clients who use periodic inventory systems. Chesley explained that the CPA firm suggests that an account called "inventory change" should be used to record for the accounting period the net increase or decrease in the merchandise inventory balance. Chesley told Espina that using this nominal account will preserve within the final adjusted trial balance the current period's actual merchandise purchases (titled "net delivered cost purchases" in Appendix 1).

When Chesley analyzed the store's insurance policies, he found a two-year policy that was acquired on April 1,2000 at a cost of $\$ 3,600$. A second policy, that cost $\$ 3,150$, only covered one year and went into affect on September 1, 2001. Chesley used brokerage documents and the Wall Street Journal to find information about Tampa Bay Sporting Goods' trading securities. The results of his analysis can be found in Table 1. He also discovered that the Bond Sinking fund simply consisted of money market accounts.

Chesley spent considerable time reading Tampa Bay Sporting Goods' legal correspondence. Letters to Mr. and Mrs. Olson revealed that the Olson's paid \$45,000 for the franchise rights to market a major sports supplier's merchandise using an official nationally known logo. Eleven years ago when the agreement was signed, attorneys advised Mr. \& Mrs. Olson that the franchise had a fifteen-year legal life. Through other correspondence, Chesley learned that on December 31, 1999, the Olson's incorporated their store in the State of Florida. Billing correspondence showed that legal and filing fees amounted to $\$ 8,445$.

Chesley learned that Tampa Bay Sporting Goods fails to use either a purchases journal or an accounts payable system. James Espina simply records all cash disbursements for merchandise inventory as a debit to the account "net delivered cost - purchases". Additionally, Espina never records reversing entries for accounts payable at the start of a new accounting period. Chesley, therefore, examined late November and December 2001 merchandise invoices. He discovered unpaid invoices amounting to $\$ 117,510$ as compared to $\$ 101,379$ of accounts payable shown in Appendix 1. 
As to other liabilities, Chesley learned that on June 1, 1999 Tampa Bay Sporting Goods issued 16\% bonds with a $\$ 112,500$ par value and obtained cash of $\$ 129,447$ for a bond yield of $12 \%$. Interest pay dates are June 1 and December 1 with a principal maturity date of June 1, 2002. When James Espina recorded premium amortization as a year-end adjusting entry at $12 / 31 / 00$, he used the straight-line method. Chesley wrote a memo to the files expressing his opinion that the straight-line method in this case does not cause a material distortion of interest expense or the year-end presentation of the liability balance. Chesley observed that while Espina correctly recorded accrued interest at 12/31/00, he did not make a reversing entry at the start of 2001. For 2001, Chesley established that accrued interest payable applies only to the bond debt instrument. Upon reviewing bank loans, Chesley verified that Tampa Bay Sporting Goods always makes the required payments on the first day of the month. James Espina correctly allocated principal and interest payments while recording monthly cash disbursements. However, Espina made no provision for the current portion of the long-term debt. Chesley found bank loan amortization schedules that provided key information (see Table 2).

Chesley analyzed the available for sale securities portfolio in conjunction with an examination of stockholders' equity. Chesley organized the information after reading brokerage documents and the Wall Street Journal (see Table 3). Then Chesley read the minutes from Board of Directors meetings held during 2000 and 2001. He found that for the first time in the store's corporate history the Board declared a cash dividend on December 31, 2001. The preferred shareholders were to be paid their full annual dividend, while the common shareholders were to get $\$ 2.50$ per share. The payment date was set for February 14, 2002. In a telephone conversation with Chesley, James Espina explained that he did not record the dividend since he could not understand the specifics of the transaction. So Chesley read the corporation's charter, made further inquiries and scheduled the information (see Table $4)$.

Chesley examined the subsidiary records for Property, Plant and Equipment. Chesley discovered a memo to Espina from a predecessor accounting firm that stated when assets are in service for less than a full-year; depreciation should be calculated using the half-year convention (assumption). He also found two errors involving an equipment sale. The first error involved an omission of an entry to record $\$ 1140$ of current year's depreciation expense prorated up to the equipment's disposal date. Secondly, in the May 2001 cash receipts journal, James Espina erroneously recorded an equipment sale by offsetting the $\$ 6,000$ check obtained with a credit only to the account "Gain on Sale of Assets". Because of these two errors, the sold equipment's book value at 12/31/00 (\$17,736 historical cost less accumulated depreciation of $\$ 14,319$ ) remains in the stores general ledger accounts found in Appendix 1. Since Espina was too busy with more usual store business, he did not have time to calculate the current year's total depreciation expense. So Chesley more closely examined the fixed asset records. He found travel logs. Records showed that the car logged 10,000 miles in 2001 and 54,000 miles in prior years. Also, the truck traveled 11,500 miles in 2001 while operating for 33,000 miles in prior years. Chesley then organized the necessary details to record depreciation expense (see Table 5).

From past experiences, Tampa Bay Sporting Goods has a credit balance in an allowance account for bad debts. Chesley researched industry guidelines and the store's own experience concerning bad debts. He concluded that bad debts could be reasonably estimated to be $.1 \%$ of total gross sales sold on account. Chesley noted that the cash receipts journal twelve-month summary for 2001 included cash sales of $\$ 277,291$. Using information prepared by James Espina, Chesley developed a schedule that aged accounts receivable (see Table 6). In the more than 90 days past due category, Chesley saw an account for $\$ 4,227$ from the Palma Verde Little League that was well over one year past due. Chesley sent James Espina a memo that cited standard policies promoted by Murray and Spiwak, CPA's. Chesley explained that any receivable amount outstanding for more than one year should be deemed worthless. When Espina telephoned Chesley about the accounts receivable memo, Espina mentioned a letter that recently arrived. Interested in the details, Chesley asked Espina to fax him a copy. The letter dated January 25, 2002, was addressed to Tampa Bay Sporting Goods and sent by First America Bank, trustee for the Bond Sinking Fund. In the letter, the bank informed the corporation that during 2001's fourth quarter, Sinking Fund Assets earned \$300 in interest revenue and now had a balance of $\$ 22,251$.

Chesley concluded his program by analyzing the corporation's income tax burden. He observed that the "Prepaid Income Taxes" asset account balance at 12/31/01 came from two sources. The first source was the 
2001estimated federal corporate quarterly income tax payments. The second source was the Olson's election to apply the year 2000 federal corporate income tax refund to its 2001 estimated income tax payments. Although Chesley did not work in the income tax division of Murray and Spiwak's practice, he knew that the State of Florida only taxes a corporation's income at 5.5\% after granting a \$5,000 exemption. Chesley learned that Tampa Bay Sporting Goods pays this state tax upon filing form F-1120. As required by federal corporate income tax law, Tampa Bay Sporting Goods Inc. made quarterly estimated tax payments. Using the instruction booklet for federal form 1120 , Chesley noted the 2001 federal corporate income tax rates (see Table 7). Chesley then went about calculating pretax income and the related income tax expense.

While finishing up the income tax calculations, Chesley received an urgent e-mail from the engagement's in-charge partner, Don Murray. Murray had just finished a telephone conversation with the nearly hysterical Mr. \& Mrs. Olson. That morning the owners of Tampa Bay Sporting Goods Inc. read a letter from their principal banklending officer. The banker told the Olson's that during a routine review of customer accounts, his boss expressed grave concern over the quality of prior year's Tampa Bay Sporting Goods Inc. reports the bank had on file. Because of this deficiency, the banker told the Olson's that future-borrowing negotiations would be severely compromised. This threat hit the Olson's very hard because they were planning on near-term renovations to the store necessitated by increased customer volume and customer complaints concerning lack of conveniences. In his e-mail message, Murray scheduled for late tomorrow afternoon an appointment with Chesley in Murray's office. The in-charge partner told the senior staff accountant to bring to the meeting all materials that he had accumulated concerning the Tampa Bay Sporting Goods Inc. account. Murray emphasized the importance of the meeting and the opportunity to impress the Olson's with the services that Murray and Spiwak CPA's could provide them.

Table 1

Trading Securities

\begin{tabular}{|lccc|}
\hline & $\begin{array}{c}\text { Market Value } \\
\text { At 12/31/00 }\end{array}$ & $\begin{array}{c}\text { Carrying Value } \\
\underline{\text { At 12/31/01 }}\end{array}$ & $\begin{array}{c}\text { Market Value } \\
\text { At 12/31/01 }\end{array}$ \\
Verizon Common & $\$ 2,214$ & $\$ 1,665$ & $\$ 1,845$ \\
Disney Common & 5,004 & 5,289 & 4,659 \\
\multicolumn{1}{c|}{ Total } & $\underline{\mathbf{7 , 0 4 4}}$ & $\underline{\mathbf{3 , 0 0 0}}$ & $\underline{3,150}$ \\
& $\underline{\mathbf{\$ 1 4 , 2 6 2}}$ & $\underline{\mathbf{\$ 9 , 9 5 4}}$ & $\underline{\mathbf{\$ 9 , 6 5 4}}$ \\
\hline
\end{tabular}

Table 2

Bank Loans Payable

\begin{tabular}{|lcc|}
\hline & Vehicle Loans & Building Mortgage \\
\cline { 2 - 3 } Date & $7 / 1 / 99$ & Refinanced $-12 / 30 / 96$ \\
Amount & $\$ 27,000$ & $\$ 450,000$ \\
Term & 3 years & 30 years \\
Interest rate & $12 \%$ & $8 \%$ \\
Monthly Payment & $\$ 897$ & $\$ 3,303$ \\
Balance at $12 / 31 / 02$ & $\$ 0$ & $\$ 419,607$ \\
Balance at $12 / 31 / 01$ & $\$ 5,193$ & $\$ 425,733$ \\
\hline
\end{tabular}


Table 3

Available For Sale Securities

\begin{tabular}{|c|c|c|c|}
\hline & \multicolumn{3}{|c|}{ Unrealized Holding } \\
\hline & $\begin{array}{c}\text { Market Value } \\
\text { At 12/31/00 }\end{array}$ & $\begin{array}{c}\text { Gain / (Loss) } \\
\text { At 12/31/00 }\end{array}$ & $\begin{array}{c}\text { Market Value } \\
\text { At 12/31/01 }\end{array}$ \\
\hline Rawlings Common & $\$ 36,501$ & $\$ 3,825$ & $\$ 42,114$ \\
\hline P \& G Common & 12,105 & 1,641 & 15,339 \\
\hline Microsoft Common & 7,263 & 222 & 6,513 \\
\hline Oracle Common & $\underline{6,015}$ & $\underline{15}$ & $\underline{5,952}$ \\
\hline Total & $\$ 61,884$ & $\underline{\$ 5,703}$ & $\$ 69,918$ \\
\hline
\end{tabular}

Table 4

Stockholders' Equity

\begin{tabular}{|lcc|}
\hline & Preferred Stock & Common Stock \\
Shares authorized & 3,000 & 60,000 \\
Par Value & $\$ 50$ & $\$ 1$ \\
Dividend terms & $9 \%$ non-cumulative & N/A \\
Shares issued & 1,500 & 20,000 \\
Treasury shares & 0 & 3,000 \\
Treasury share cost & N/A & $\$ 12.50$ \\
\hline
\end{tabular}


Table 5

Fixed Assets

\begin{tabular}{|lccc|}
\hline Assets & $\begin{array}{c}\text { Date } \\
\text { Acquired }\end{array}$ & $\underline{\text { Cost }}$ & $\begin{array}{c}\text { Accumulated } \\
\text { Depreciation 12/31/00 }\end{array}$ \\
Building & $12 / 88$ & $\$ 51,075$ & $\$-0-$ \\
Furniture & $12 / 88$ & 744,126 & 218,810 \\
Furniture & $12 / 89$ & 22,800 & 20,520 \\
Equipment - Fork Lifts & $9 / 00$ & 15,051 & 677 \\
Equipment - Office & $5 / 01$ & 22,281 & $-0-$ \\
Car & $10 / 00$ & 6,744 & 607 \\
Truck & $5 / 96$ & 15,345 & 12,431 \\
& $7 / 99$ & 41,367 & 20,477 \\
Assets & & & Method of \\
Building & Estimated & Salvage & Depreciation \\
Furniture & Useful Life & Value & Straight-line \\
Equipment - Fork Lifts & 40 years & \$43,935 & Straight-line \\
Equipment - Office & 10 years & $10 \%$ of cost & Straight-line \\
Car & 7 years & $10 \%$ of cost & Straight-line \\
Truck & 5 years & $10 \%$ of cost & Miles used \\
\hline
\end{tabular}

Table 6

Accounts Receivable

\begin{tabular}{|cr|}
\hline Davs Past Due & $\underline{\text { Amount }}$ \\
Not past due & $\$ 12,198$ \\
Less than 30 & 2,265 \\
30 & 23,277 \\
60 & 14,502 \\
90 & 3,474 \\
More than 90 & $\underline{\mathbf{6 , 9 3 9}}$ \\
Total & $\underline{\mathbf{\$ 6 2 , 6 5 5}}$ \\
\hline
\end{tabular}

Table 7

Federal Corporate Income Tax Rates

Taxable income $\$ 50,000$ or less.

Taxable income over $\$ 50,000$ but not over $\$ 75,000$.

Taxable income over $\$ 75,000$ but not over $\$ 10,000,000$

Taxable income over $\$ 10,000,000$ but not over $\$ 15,000,000 \ldots \ldots$
$15 \%$

$25 \%$

$34 \%$

$35 \%$ 


\section{Appendix 1}

\begin{tabular}{|c|c|c|c|c|c|c|c|c|c|c|}
\hline \multirow{2}{*}{$\begin{array}{l}\text { TAMPA BAY } \\
\text { SPORTING GOODS INC. CASE }\end{array}$} & \multicolumn{2}{|c|}{$\begin{array}{c}\text { Unadjusted Trial Balance } \\
\text { December 31, } 2001\end{array}$} & \multicolumn{2}{|c|}{$\begin{array}{c}* * * \text { ADJUSTING ENTRIES } * * * * \\
\text { December 31, } 2001\end{array}$} & \multicolumn{2}{|c|}{$\begin{array}{c}\text { Adjusted Trial Balance } \\
\text { December 31, 2001 }\end{array}$} & \multicolumn{2}{|c|}{$\begin{array}{c}\text { Income Statement } \\
\text { December 31, 2001 }\end{array}$} & \multicolumn{2}{|c|}{$\begin{array}{c}\text { Balance Sheet } \\
\text { December 31, 2001 }\end{array}$} \\
\hline & dr. & cr. & dr. & cr. & dr. & cr. & dr. & cr. & dr. & cr. \\
\hline CASH & 47,325 & & & & 47,325 & & & & 47,325 & \\
\hline TRADING SECURITIES & 9,954 & & & & 9,954 & & & & 9,954 & \\
\hline ACCOUNTS RECEIVABLE & 62,655 & & & & 62,655 & & & & 62,655 & \\
\hline ALLOWANCE FOR DOUBTFUL A/C & & 2,265 & & & & 2,265 & & & & 2,265 \\
\hline NOTE RECEIVABLE & 7,500 & & & & 7,500 & & & & 7,500 & \\
\hline MERCHANDISE INVENTORY & 260,421 & & & & 260,421 & & & & 260,421 & \\
\hline OFFICE SUPPLIES & 3,597 & & & & 3,597 & & & & 3,597 & \\
\hline $\begin{array}{l}\text { PREPAID INSURANCE } \\
\end{array}$ & 5,400 & & & & 5,400 & & & & 5,400 & \\
\hline PREPAID INCOME TAX & 22,980 & & & & 22,980 & & & & 22,980 & \\
\hline AVAILABLE FOR SALE SECURITIES & 61,884 & & & & 61,884 & & & & 61,884 & \\
\hline BOND SINKING FUND & 21,951 & & & & 21,951 & & & & 21,951 & \\
\hline & & & & & & & & & & \\
\hline LAND & 51,075 & & & & 51,075 & & & & 51,075 & \\
\hline$\overline{\text { BUILDING }}$ & 744,126 & & & & 744,126 & & & & 744,126 & \\
\hline EQUIPMENT & 141,324 , & & & & 141,324, & & & & 141,324, & \\
\hline $\begin{array}{l}\text { ACCUMULATED DEPRECIATION } \\
\end{array}$ & & 287,841 & & & & 287,841 & & & & 287,841 \\
\hline & & & & & & & & & & \\
\hline FRANCHISE COSTS & 15,000 & & & & 15,000 & & & & 15,000 & \\
\hline ORGANIZATION COSTS & 6,756 & & & & 6,756 & & & & 6,756 & \\
\hline NOTES PAYABLE DUE IN ONE YEAR & & & & & & & & & & \\
\hline & & & & & & & & & & \\
\hline CURRENT PORTION OF LT DEBT & & & & & & & & & & \\
\hline ACCOUNTS PAYABLE & & 101,379 & & & & 101,379 & & & & 101,379 \\
\hline PAYROLL TAXES PAYABLE & & 14,452 & & & & 14,452 & & & & 14,452 \\
\hline SALES TAXES PAYABLE & & 13,711 & & & & 13,711 & & & & 13,711 \\
\hline $\begin{array}{l}\text { ACCRUED INTEREST PAYABLE } \\
\end{array}$ & & 4,509 & & & & 4,509 & & & & 4,509 \\
\hline & & & & & & & & & & \\
\hline CORP. INCOME TAXES PAYABLE & & & & & & & & & & \\
\hline LOAN PAYABLE - LONG TERM & & 5,193 & & & & 5,193 & & & & 5,193 \\
\hline BONDS PAYABLE & & 112,500 & & & & 112,500 & & & & 112,500 \\
\hline PREMIUM ON BONDS PAYABLE & & 8,003 & & & & 8,003 & & & & 8,003 \\
\hline MORTGAGE PAYABLE & & 425,733 & & & & 425,733 & & & & 425,733 \\
\hline & & & & & & & & & & \\
\hline
\end{tabular}




\begin{tabular}{|c|c|c|c|c|c|c|c|c|c|c|}
\hline \multirow[t]{2}{*}{$\begin{array}{l}\text { TAMPA BAY } \\
\text { SPORTING GOODS INC. CASE }\end{array}$} & \multicolumn{2}{|c|}{$\begin{array}{l}\text { Unadjusted Trial Balance } \\
\text { December 31, } 2001\end{array}$} & \multicolumn{2}{|c|}{$\begin{array}{c}\text { F**ADJUSTING ENTRIES }^{* * * * *} \\
\text { December 31, } 2001\end{array}$} & \multicolumn{2}{|c|}{$\begin{array}{c}\text { Adjusted Trial Balance } \\
\text { December 31, } 2001\end{array}$} & \multicolumn{2}{|c|}{$\begin{array}{l}\text { Income Statement } \\
\text { December 31, } 2001\end{array}$} & \multicolumn{2}{|c|}{$\begin{array}{c}\text { Balance Sheet } \\
\text { December 31, } 2001\end{array}$} \\
\hline & dr. & cr. & dr. & cr. & dr. & cr. & dr. & cr. & dr. & cr. \\
\hline COMMON STOCK & & 20,000 & & & & 20,000 & & & & 20,000 \\
\hline PREFERRED STOCK & & 75,000 & & & & 75,000 & & & & 75,000 \\
\hline PD IN CAPITAL IN EXCESS OF PAR & & 258,600 & & & & 258,600 & & & & 258,600 \\
\hline RETAINED EARNINGS & & 61,935 & & & & 61,935 & & & & 61,935 \\
\hline TREASURY STOCK & 37,500 & & & & 37,500 & & & & 37,500 & \\
\hline UNREALIZED HOLDING GAIN/LOSS & & 5,703 & & & & 5,703 & & & & 5,703 \\
\hline & & & & & & & & & & \\
\hline SALES & & $2,341,443$ & & & & $2,341,443$ & & $2,341,443$ & & \\
\hline SALES DISCOUNTS & 40,269 & & & & 40,269 & & 40,269 & & & \\
\hline SALES RETURN ALLOW & 13,977 & & & & 13,977 & & 13,977 & & & \\
\hline & & & & & & & & & & \\
\hline DIVIDEND REVENUE & & 2,064 & & & & 2,064 & & 2,064 & & \\
\hline INTEREST REVENUE & & 2,310 & & & & 2,310 & & 2,310 & & \\
\hline BOND SINKING FUND REVENUE & & 1,485 & & & & 1,485 & & 1,485 & & \\
\hline GAIN ON SALE OF ASSETS & & 8,061 & & & & 8,061 & & 8,061 & & \\
\hline UNREALIZED HOLDING GAIN & & & & & & & & & & \\
\hline NET DELIVERED COST -- PURCHASES & $1,602,141$ & & & & 1602141 & & 1602141 & & & \\
\hline & $1,602,141$ & & & & & & & & & \\
\hline SELLING EXPENSES & 292,347 & & & & 292,347 & & 292,347 & & & \\
\hline ADMINISTRATIVE EXPENSES & 145,545 & & & & 145,545 & & 145,545 & & & \\
\hline PAYROLL TAXES & 33,045 & & & & 33,045 & & 33,045 & & & \\
\hline PROPERTY TAXES & 30,714 & & & & 30,714 & & 30,714 & & & \\
\hline UTILITIES EXPENSE & 28,785 & & & & 28,785 & & 28,785 & & & \\
\hline & & & & & & & & & & \\
\hline REPAIR EXPENSE & 5,469 & & & & 5,469 & & 5,469 & & & \\
\hline PROFESSIONAL FEES & 7,458 & & & & 7,458 & & 7,458 & & & \\
\hline BAD DEBTS EXPENSE & & & & & & & & & & \\
\hline DEPRECIATION EXPENSE & & & & & & & & & & \\
\hline AMORTIZATION EXPENSE & & & & & & & & & & \\
\hline & & & & & & & & & & \\
\hline INTEREST EXPENSE & 52,593 & & & & 52,593 & & 52,593 & & & \\
\hline LOSS ON SALE OF ASSETS & 396 & & & & 396 & & 396 & & & \\
\hline UNREALIZED HOLDING LOSS & & & & & & & & & & \\
\hline INCOME TAX EXPENSE & & & & & & & & & & \\
\hline
\end{tabular}




\begin{tabular}{|c|c|c|c|c|c|c|c|c|c|c|}
\hline \multirow[t]{2}{*}{$\begin{array}{l}\text { TAMPA BAY } \\
\text { SPORTING GOODS INC. CASE }\end{array}$} & \multicolumn{2}{|c|}{$\begin{array}{l}\text { Unadjusted Trial Balance } \\
\text { December 31, } 2001\end{array}$} & \multicolumn{2}{|c|}{$\begin{array}{l}\text { ***ADJUSTING ENTRIES } * * * * \\
\text { December 31, } 2001\end{array}$} & \multicolumn{2}{|c|}{$\begin{array}{l}\text { Adjusted Trial Balance } \\
\text { December 31, 2001 }\end{array}$} & \multicolumn{2}{|c|}{$\begin{array}{l}\text { Income Statement } \\
\text { December 31, 2001 }\end{array}$} & \multicolumn{2}{|c|}{$\begin{array}{c}\text { Balance Sheet } \\
\text { December 31, } 2001\end{array}$} \\
\hline & dr. & cr. & dr. & cr. & dr. & cr. & dr. & cr. & dr. & cr. \\
\hline TOTALS & $3,752,187$ & $3,752,187$ & & & $3,752,187$ & $3,752,187$ & $2,252,739$ & $2,355,363$ & $1,499,448$ & $1,396,824$ \\
\hline Net Income (Net Loss) & & & & & & & 102,624 & & & 102,624 \\
\hline
\end{tabular}




\section{Appendix 2}

TAMPA BAY SPORTING GOODS INC. INCOME STATEMENT (PRELIMINARY CALCULATIONS)
FOR THE YEAR ENDED DECEMBER 31,2001

\section{NET SALES}

COST OF GOODS SOLD

OPERATING EXPENSES

SELLING EXPENSES
ADMINISTRATIVE EXPENSES

PAYROLL TAXES

UTILITIES EXPENSE

DEPRECIATION EXPENSE

REPAIR EXPENSE

BAD DEBTS EXPENSE

TOTAL OPERATING EXPENSES

\section{OPERATING INCOME}

OTHER REVENUES AND GAINS: DIVIDENDS AND INTERES

OTHER EXPENSES AND LOSSES

$$
\begin{aligned}
& \text { INTEREST EXPENSE } \\
& \text { OTHER LOSSES }
\end{aligned}
$$

INCOME BEFORE INCOME TAXES

INCOME TAXES

NET INCOME
TAMPA BAY SPORTING GOODS INC. BALANCE SHEET (PRELIMINARY CALCULATIONS)
DECEMBER 31,2001

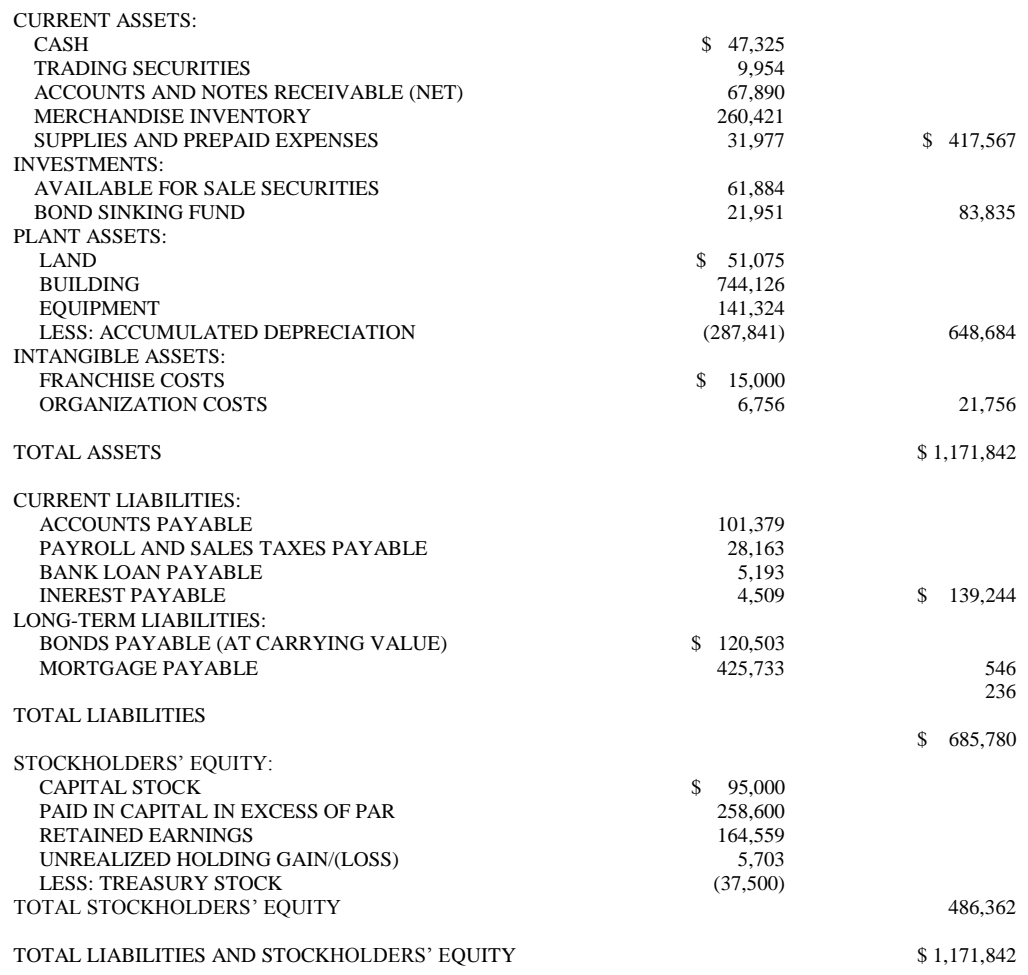




\section{Appendix 3 Greg Chesley's Review Program For Tampa Bay Sporting Goods Inc.}

1. Prepare the bank reconciliation as of $12 / 31 / 01$.

2. Determine Tampa Bay Sporting Goods' method of controlling merchandise inventory. Observe and assist with the physical merchandise inventory count to be taken on January 1, 2002. If necessary, assist the bookkeeper in establishing a standard procedure to record the inventory change since the last financial statement preparation.

3. Inquire about the January 2, 2002 count to establish an ending balance of unused office supplies.

4. Analyze the store's insurance policies.

5. Review the trading securities portfolio. Establish fair market value at 12/31/01.

6. Review legal correspondence that explains the franchise relationship that Tampa Bay Sporting Goods Inc. has with a major sporting goods supplier. Search to establish the legal life of this arrangement.

7. Examine legal correspondence that describes the costs necessary to organize Tampa Bay Sporting Goods Inc. as a corporation in the state of Florida. Make sure that any cost amortization is in agreement with the same minimum number of years allowed by the IRS for the income tax amortization deduction.

8. Determine how accounts payable get recorded. Make sure that client is in compliance with the requirements of accrual accounting.

9. Analyze the outstanding Bonds Payable. Determine if premium amortization has been properly calculated and recorded.

10. Verify any interest accruals.

11. Determine if any long-term debt has a current portion due within one year of Balance Sheet date.

12. Review the available for sale securities portfolio. Establish fair market value at 12/31/01. Determine if unrealized gains/losses appear in the Balance Sheet as required by GAAP.

13. Read the minutes for all Board of Directors meetings during 2000 and 2001. Establish the existence of any dividend declaration. Read the corporate charter to determine the classes of stock, any contractual preferences, and the initial amount of shares authorized.

14. Examine the subsidiary records for property, plant and equipment. Establish the policy for recording depreciation for individual fixed assets that are either sold or acquired during the current year.

15. Review any transactions that involve the disposal of fixed assets.

16. Vouch or determine the depreciation expense calculation.

17. Research industry guidelines for bad debts expense as well as Tampa Bay Sporting Goods' past experience with bad debts.

18. Prepare an accounts receivable aging schedule. Determine if any accounts should be written off.

19. Inquire if the Bond Sinking Fund trustee has sent the corporation some sort of report for 2001.

20. Determine how estimated taxes are recorded. Calculate the current year's income tax expense. 


\section{Appendix $4 \quad$ Tampa Bay Sporting Goods Inc. Case}

Phase 1 - Establish worksheet using given unadjusted trial balance found in Appendix 1.

(Phase 1 requires a fundamental skill with using Microsoft's Excel.)

\section{DUE DATE:}

Phase 2 - Review assets for proper Balance Sheet Presentation.

(Phase 2 implements Appendix 3, items 1 - 7.)

DUE DATE:

Phase 3 - Review current and long-term liabilities for proper Balance Sheet presentation.

(Phase 3 implements Appendix 3, items 8 - 11.)

\section{DUE DATE:}

Phase 4 - Establish stockholders' equity as an alternative to the Balance Sheet and the Income Statement. (Phase 4 implements Appendix 3, items 12 \& 13.)

\section{DUE DATE:}

Phase 5 - Review revenue and expense accounts in order to establish a reliable Income Statement.

(Phase 5 implements Appendix 3, items 14 - 20.)

(After responding to Appendix 3, item 19, you can then process the twentieth (last) item in Appendix 3.

Item 20 requires a calculation of "pre-tax" income in order to establish income tax expense for the year.)

DUE DATE: 


\section{Teaching Notes}

This case can be best used as a review assignment that functions concurrently with accounting theory lessons taught at the beginning of the Intermediate Accounting I course. At the instructor's option, the case divides into five phases. Business related issues can be talked about during each phase or deferred until the end of the case. (See end of teaching notes for discussion about accounting as a business.) In the first phase, students will need to enter into their worksheet the unadjusted trial balance at 12/31/01 (Appendix 1) that Greg Chesley, senior staff accountant, organized using Microsoft's Excel. Phase 1 encourages organization skills that will expedite adjustments, corrections, reclassifications and tentative calculations of net income necessary to evaluate the reasonableness of those entries. To accomplish this goal, students should develop a worksheet template using Microsoft's Excel. To assist students, who understand Excel fundamentals, the instructor needs to spend time explaining a general framework for a worksheet template. The recommended form for a worksheet template is page one, the balance sheet accounts; page two, the income statement accounts; and lastly page three, the adjusting entries. The adjusting entries should flow into pages one and two's adjustment columns that in turn will automatically produce the adjusted trial balance columns and as appropriate also update either the income statement or balance sheet columns. Instructors should emphasize to students that once properly established the worksheet template can be reused so as to standardize future similar projects. The Phase 1 object lesson is to understand the preliminary work necessary to process a client initially and then subsequently on a routine basis.

The second phase reviews lessons that primarily deal with assets and their presentation in the Balance Sheet. Fundamentally, the case assets reflect the basic accounting cycle of a merchandising company regardless of the entity's legal form. However, the seventh and final entry in Phase 2 deals with Organization Costs, a deferred charge synonymous with a corporation. Included in this second phase is an account called "inventory change", the author's invention. This unique account found in the second adjustment reflects a major aspect of a periodic inventory system. In such a system the calculation of cost of goods sold expense is a function not only of the net delivered cost of purchases but also the change in balance from beginning to ending inventory. Using this aptly named account formally demonstrates that inventory change is an element of cost of goods sold. Other Phase 2 adjustments involve office supplies expense, prepaid insurance expense, fair market valuation for trading securities, and intangible asset amortization. Also a correcting entry must be made in Phase 2 in order to recognize unrecorded cash sales that understated the cash account.

The third phase contains lessons dealing with current and long-term liabilities. The first entry in the third phase calls for establishing current accounts payable while reversing last year's balance. This entry emphasizes why an entity might hire a CPA firm to assure compliance with the concepts of accrual accounting. While the bookkeeper does a good job recording cash outflows, the CPA firm staff accountant in this case must fine-tune the unadjusted trial balance into a GAAP sanctioned product. On a similar note, the current year's accrued interest must be recorded while last year's interest payable needs to be reversed out. A necessary further refinement involves a reclassification entry needed so that short-term liabilities contain the current portion of long-term debt. Finally, the third phase contains the adjustment necessary when a bond was issued at other than par value. The case opts for straight-line amortization. This choice was made to easily demonstrate amortization's impact upon bond book value while still maintaining the case's theme of a review exercise to be done prior to teaching in Intermediate Accounting all the various detailed aspects associated with a topic like bonds payable.

The brief fourth phase concentrates upon lessons that are unique to stockholders' equity. While available for sale securities are assets, they require year-end fair market value adjustments that impact stockholders' equity. By separating trading securities into an earlier phase, the case uses the fourth phase to underline the special treatment of unrealized holding gains / loss when they derive from the available for sale portfolio. The instructor can emphasize that using Stockholders' Equity to adjust asset valuation is a mechanism that bypasses the Income Statement. Also, dividends paid should be kept out of the Income Statement. The bookkeeper in the case did not know how to record declared cash dividends. Therefore an opportunity exists to instruct that like the drawing account used by an unincorporated business, dividends are not a business expense that reduces the net income calculation. Thus net income remains unaffected. While a relatively short phase, the fourth phase serves an important transitional role just as the Statement of Stockholders' Equity transitions the financial statements from the Income Statement 
to the Balance Sheet. Students should be made to appreciate that Phase 4 net income is the same as Phase 3 because Phase 4 deals only with Balance Sheet accounts. This lesson drives home the point that only "true" adjusting entries change the calculation of net income. Therefore, while the fifth and final case phase reviews the Income Statement, the fourth phase prepares for such a review by reminding students that Stockholders' Equity offers an alternative to using the Income Statement. Stockholders' Equity serves that function by providing a final location for transactions that do not truly impact earnings.

The fifth and last phase spotlights Income Statement issues and the resulting impact upon the related Balance Sheet accounts. The first two entries in this final phase involve correcting the bookkeeper's method to record a fixed asset disposal. As a subset to this recording error, the bookkeeper failed to update depreciation to the point of disposal. Further omissions from the unadjusted trial balance form the basis for two additional entries. First, the CPA firm staff accountant calculates depreciation expense for the client after scheduling the fixed asset details. Secondly, after researching and reviewing the current status of accounts receivable, the staff accountant calculates and records bad debts expense. While preparing an aging of accounts receivable in order to help decide the appropriate bad debts expense amount, the public accountant discovered a specific receivable that could be deemed uncorrectable. The outside accountant also found correspondence from the bond sinking fund trustee. In the letter, the trustee informed the corporation that the fund earned interest revenue for the fourth quarter. Like so much of phase five, the bookkeeper did not record a transaction that this time increased interest revenue as well as an asset (the related bond sinking fund). The final Phase 5 adjustment (the twentieth and last for the case) calculates the corporation's income tax expense. Before this conclusive adjustment can be made, the student needs to post to the worksheet all previous adjustments. Then the student should be instructed to use the worksheet to calculate "pre-tax" income. This last step reveals the final nature of the income tax adjustment. Further, this calculation demonstrates the help that an electronic worksheet can provide when recognizing the final expense for income taxes. Even if an instructor elects to omit the five phases, he / she should emphasize to students the need to calculate "pre-tax" income before finalizing the case.

As an overall goal, this case attempts to get a student to grasp the broader implications of transactional processing. Adjustments make a difference. Therefore when used, each case phase will generate a different net income. And the way adjustments must be processed depends upon the initial organization of the unadjusted data. So that the ultimate communicative effectiveness of financial reports germinates from appropriate transactional processing.

When electing to use all or some of the case phases, the student should obtain the correct net income for each phase before being allowed to proceed to the next phase. If the instructor decides to consolidate phases (for example assets and liabilities), then the correct balancing net income will be that of the later phase as presented below. The correct net incomes by phases are:

Phase 1 (The same as Appendix 1)

$\$ 102,624$

Phase 2 (Involves adjustments made in response to Appendix 3, items 1 - 7)

$\$ 143,697$

Phase 3 (Involves adjustments made in response to Appendix 3, items 8 - 11)

$\$ 136,224$

Phase 4 (Involves adjustments made in response to Appendix 3, items 12 \& 13

$\$ 136,224$

Phase 5 (Involves adjustments made in response to Appendix 3, items 14 - 20)

$\$ 74,938$

(Note: in phase 5 in order to correctly calculate the last adjustments, pre tax income must be $\$ 101,020$ ) 
Maintaining the five separate phases is a good way to control student errors. A suggested student assignment sheet appears as case Appendix 4.

What distinguishes the Tampa Bay Sporting Goods Inc. case from a simple adjusting journal entries review exercise? The distinctive factor is the prevailing theme that not only does accounting function within the world of business, providing accounting services is itself also a business. And a business requires people who are motivated to succeed. Two motivated characters and one management team act within the case. The most prevalent character is Greg Chesley, a senior staff accountant employed by Murray and Spiwak, CPA's. The other major motivated character is Don Murray, partner in-charge of the engagement. Finally, the management team that owns and operates Tampa Bay Sporting Goods Inc., Mr. \& Mrs. Olson, have the major stake in the case's ultimate outcome.

What motivates Greg Chesley? He wants to succeed within an economic environment that reserves major financial rewards for entrepreneurs. The state of Florida does not tax individual income. Therefore, pay levels are lower than states with high personal income and real estate taxes. So to make substantial economic gains, a professional must either prove his / her value to an established entity or start one's own business. Having just relocated to Florida, Chesley realistically only has the option to impress those who manage an existing CPA firm. In this case Chesley tries to document his value to the Tampa Bay Sporting Goods' engagement. He writes a plan that could form the basis for a review engagement (see Appendix 3). He constructs preliminary "pre-adjusting entry" financial statements (see Appendix 2). And Chesley writes memos to James Espina, Tampa Bay Sporting Goods' bookkeeper. These memos provide evidence that he has been training Espina as per instructions given to him by his boss, one of the firm's primary partners Don Murray. Chesley also wrote a memo to the files that documented his use of professional judgment.

What motivates Don Murray? He is a man of accomplishments, witness his ownership of a professional service entity. Murray must understand the Tampa Bay economy to be able to succeed in a financially oriented business. He has made a judgment that the Tampa Bay Sporting Goods Inc. entity has potential. Murray can envision future consulting engagements and advanced tax planning work. Accomplished people who are in positions of authority do not like to be proved wrong. Given the booming economic times in the region, the firm can afford to be choosy about clients. Murray does not want to embarrass himself at a partnership meeting by explaining why he wasted the firm's resources on an inconsequential or even worse on a worthless client.

What motivates Mr. \& Mrs. Olson? Undoubtedly they are hard working people who need to manage their time and resources. If the proven veteran bookkeeper is having problems keeping up with processing transactions and coping with transaction complexities, then one might conclude that managing the business in its current form must be an increasing challenge. At the end of the case, the Olson's are very nervous about being unable to obtain financing necessary to improve and expand the store. A reasonable conclusion would be that Mr. \& Mrs. Olson want to be assured that they can control their business and that their efforts will lead to rewards commensurate with the risks they are taking as entrepreneurs. 
Notes 